\title{
PSZEUDOCEREÁLIÁKBÓL KÉSZÍTETT INNOVATÍV PRÓBATERMÉKEK VIZSGÁLATA ÉS FOGYASZTÓI ÉRTÉKELÉSE
}

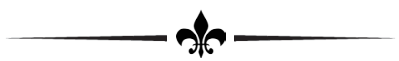

\section{EXAMINATION AND CONSUMERS' EVALUATION OF NEW PILOT PRODUCTS FROM PSEUDOCEREALS} \\ ${ }^{1} J E V C S A ́ K$, SZINTIA \\ ${ }^{2}$ SIPOS, PÉTER \\ ia \\ ${ }^{1}$ Debreceni Egyetem, Mezőgazdaság-, Élelmiszertudományi és Környezetgazdálkodási Kar, Élelmiszertechnológiai Intézet, \\ Kerpely Kálmán Doktori Iskola (University of Debrecen, Faculty of Agricultural and Food Sciences and Environmental Management, \\ Institute of Food Technology, Kerpely Kálmán Doctoral School) \\ H-4032 Debrecen, Böszörményi út 138 . \\ e-mail: jevcsak@agr.unideb.hu \\ ${ }^{2}$ Debreceni Egyetem, Táplálkozástudományi Intézet (University of Debrecen, Institute of Nutrition) \\ H-4032 Debrecen, Böszörményi út 138
}

\begin{abstract}
a Nowadays the importance of the use of pseudocereals is increasing, especially in the diet of health conscious consumers and those who follow reform diet. In our research we produced pilot products with health-beneficial properties. The main ingredients were pseudocereals, such as buckwheat, amaranth and quinoa flour, and our aim was to get more information about their possible uses in nutrition. These grains have typical (buckwheat) or bitter taste (amaranth), therefore our second aim was to survey the consumers' opinions, which help us to determine further direction of development. In our research we produced bakery pilot products from the previously defined mixtures of different gluten free flours and natural additives, taking into account the consumer's demands, because more and more people are looking for the opportunity to reduce the gluten intake improving their health condition. Physical and chemical parameters of pilot products were determined. Finally, we evaluated the consumers' opinions by a sensory test and questionnaire, therefore, we got results not only about the quality of products but the consumers' preference orders too.
\end{abstract}

KuLCSSZAVAK: pszeudocereáliák, hajdina, amaránt, quinoa, fogyasztói értékelés

JEL-KóDOK (JEL CODES): I19

DOI: https://doi.org/10.20494/TM/6/1/4

\section{BEVEZETÉS - INTRODUCTION}

Napjainkban egyre nagyobb jelentőségű a pszeudocereáliák, vagy más néven az álgabonák felhasználása, különösen az egészségesen táplálkozó és a reformtáplálkozók étrendjében (LÉDER et al., 2012). Kutatásunk során olyan újszerü próbatermékeket állítottunk elő, melyek számos kedvező táplálkozás-élettani hatással rendelkeznek. Az általunk ritkábban
KEYwORDS: pseudocereals, buckwheat, amaranth, quinoa, consumer evaluation

fogyasztott pszeudocereáliák, mint a hajdina, az amaránt és a quinoa lisztek felhasználási lehetőségeinek megismerése volt számunkra az egyik legfontosabb feladat. Ezek a lisztek jellegzetes (hajdina) vagy éppen keserü (amaránt) utóízzel rendelkeznek, ezért a kutatásunkban a második legfontosabb feladat a fogyasztói vélemények felmérése, hiszen segítséget nyújt a további fejlesztési irányvonal meghatározásában. A kísérlet során, a fogyasztói igényeknek meg- 
felelően, azok kielégítésére további gluténmentes lisztek keverékét alkalmaztuk, ugyanis egyre többen keresik a lehetőséget a glutén beviteli mennyiségének csökkentésére, a jobb közérzet elérése érdekében. Így tehát az adott lisztek meghatározott arányokban való keverésével, valamint természetes dúsítóanyagok hozzáadásával sütőipari próbatermékek előállítását végeztük el. Ezt követően a számos variációban elkészült próbatermékek fizikai és kémiai paramétereit értékeltük. Végül az elkészült próbatermékek érzékszervi bírálatát kérdőíves felméréssel végeztük el, így nem csak a termékek minőségéről kaphattunk visszajelzést, de a fogyasztók preferencia-sorrendjéról is.

\subsection{Az álgabonák (pszeudocereáliák) jellemzői - Properties of Pseudocereals}

A hajdina (Fagopyrum esculentum (Moench)), amaránt (Amaranthus spp.) és quinoa (Chenopodium quinoa (Willd)) ősi növényeinknek számítanak. Növénytani besorolás szerint nem gabonák, de kémiai összetevőik és falhasználásuk alapján igen hasonlóak azokhoz (TAYLOR, 2017). FLETCHER (2016) leírja, hogy a pszeudo- előtag jelentése „hamis”. A hajdina, vagy másik ismert nevén a pohánka, a Fagopyrum nemzetségbe és a Polygonaceae családba tartozik. Termesztését először Ázsiában kezdték meg. Ma a legnagyobb mennyiségben Európában termesztik és fogyasztják (53,1\%), melyet Ázsia követ (38,6\%). További nagy termesztő országokhoz tartozik Oroszország, Kína, Ukrajna és Franciaország. Magyarországon ősi ételnek számít (LÉDER et al., 2012). A pohánka ezerszemtömege 15 és $35 \mathrm{~g}$ között mozog. A szemek gazdag tápanyag-forrásnak tekinthetőek (TÖMÖSKÖZI és LANGÓ, 2017). Értékes összetevőihez tartozik a keményítő, a fehérje, az élelmi rost és további értéknövelője az antioxidáns vegyületek és nyomelemek jelenléte (KRKOŠKOVÁ és MRÁZOVÁ, 2005). A szemek szénhidrát tartalma 58\%-73\% között változik. A keményítő szemcséinek mérete 2 és $15 \mu \mathrm{m}$ közötti értéket vesz fel. Élelmi rost tartalma 7,0-10,9\%. Fehérjetartalma 12\% körüli érték, mely közel azonos a búza fehérjetartalmával. Aminosavak tekintetében a szemekben a lizin, treonin és valin található meg legnagyobb mennyiségben. Zsírtartalma 2\%-4\% között mozog, mely fóleg a csírában található. A zsírsavak arányát tekintve 75-80\%-ban a telítetlen zsírsavak vannak jelen, melyekből a többszörösen telítetlenek hányada 40\%. Ásványi anyag tartalmát illetően közel azonos az amaránttal, de megelőzi a quinoa elemtartalmát. Kiemelendő a $\mathrm{K}, \mathrm{Mg}, \mathrm{Ca}, \mathrm{Na}, \mathrm{Cu}, \mathrm{Zn}, \mathrm{Fe}$ és $\mathrm{Mn}$ tartalma. A hajdina igen jó forrása a B vitaminok csoportjának, nagyobb mennyiségben megtalálható a $\mathrm{B}_{1}, \mathrm{~B}_{2}, \mathrm{~B}_{3}, \mathrm{~B}_{5}$ és $\mathrm{B}_{6}$ vitamin, de az $\mathrm{E}$ vitamin is megtalálható a szemekben. A növény fitokemikáliákban gazdag, 6 féle flavonoidot izoláltak a hajdinából: a rutint, quercetint, orientint, vitexint, izovitexint és isoorientint. Az egyetlen álgabona, mely rutint tartalmaz. A hajdinát régóta használják kínai terápiákban számos betegség kezelésében. Ma funkcionális élelmiszerek nyersanyagát képezi jótékony hatásának köszönhetően (TÖMÖSKÖZI és LANGÓ, 2017). LÉDER et al. (2012) számos beltartalmi vizsgálatot végeztek hántolt hajdinára és a hajdina levéllisztjére vonatkozóan. Az eredmények azt mutatták, hogy mindkét esetben magas biológiai értékü élelmiszer alapanyagról van szó, mely vitaminok, ásványi anyagok és antioxidáns hatású vegyületek kiváló forrása.

Az amaránt az Amaranthus nemzetségbe és az Amaranthaceae családba tartozó fajok gyüjtőneve. Legnagyobb termesztők közé tartozik Dél-Amerika, Afrika, Közép- és Délkelet-Ázsia. Európában mindössze ezer hektáron termesztik. Magyarországon a 80-as évektől kezdődően honosodott (LÉDER et al., 2012). Az amaránt a gabonákhoz viszonyítva nagyobb mennyiségben tartalmaz zsírt és fehérjét is. Ez utóbbi mennyisége 13,1\% és 21,0\% között mozog (D’AMICO és SCHOENLECHNER, 2017). Legnagyobb arányban az albumin található meg a szemben, $40 \%$, a globulin 20\%-ban, a glutelin 25-30\%-ban, míg a legalacsonyabb mennyiségben a prolamin van jelen, 2\%-3\% (VENSKUTONIS és KRAUJALIS, 2013). Egy tanulmány alapján az amarántban található fehérje 89\%-os emészthetőséggel jellemezhető (FERREIRA és AREAS, 2004; KUMAR et al., 2016). Zsírtartalma egész széles tartományban mozoghat, 3,24\% és 8,60\% között. Zsírsavai közül a linolsav, az olajsav és a palmitinsav a meghatározó. Keményítő mennyiségét tekintve alacsonyabb értéket mutat, mint a legtöbb gabona, 48\%-69\%. Diétás rost tartalmát tekintve 
ugyancsak változó értékeket vehet fel, ez 8,0\%tól, akár 20,6\%-ig is terjedhet. Az amaránt esetében ugyancsak megtalálhatóak a kémiai összetevők között a B vitaminok. Makro- és mikroelem tartalma magasnak tekinthető, melyek közül említést érdemel a Ca, mely ötször nagyobb mennyiségben van jelen, mint a búza esetében. Bioaktív vegyületek közül megtalálhatóak a fenolos vegyületek, flavonoidok, tannin, de a kumarinok is. Az amaránt felhasználása széleskörü, főzve, sütve, pelyhesítve fogyasztják, sütemények, kekszek, kenyerek és tészták elkészítésénél is kiváló, illetve nagyon népszerü ma az extrudált formája (D’AMICO és SCHOENLECHNER, 2017).

A quinoa a Chenopodium nemzetségbe és az Amaranthaceae családba tartozik. A legnagyobb termesztők közé Peru és Bolívia tartozik, ahol a világ quinoa termesztésének 90\%a tartozik. Nagyobb mennyiségben előfordul Olaszországban, Franciaországban, Angliában, Svédországban, de Dániában is. Magyarországon termesztése még nem valósult meg (LÉDER et al., 2012). A fehérjetartalma hasonló a gabonák fehérjetartalmához, 13\%-15\% között mozog, de akár 8-22\% is lehet fajtától függően. Zsírtartalma magasnak mondható, négyszer magasabb, mint a búza esetében, 4,0-9,7\%. Telítetlen zsírsavainak aránya 82,7-85,0\% között változhat. Legnagyobb hányadát a linolsav (50\%) és olajsav (20\%) teszi ki. A quinoa szemekben leginkább B2 és E vitamin található nagyobb mennyiségben. Bioaktív komponensei közül jelen vannak a keserú ízt adó szaponinok, melyek antinutriensként funkcionálnak, azonban ezek a vegyületek egyben a betegségek megelőzésében is részt vesznek, ugyanis koleszterin csökkentő és gyulladásgátló tulajdonságokkal is rendelkeznek. Fitinsavak ugyancsak megtalálhatóak a szemekben, amelyek antioxidáns hatással rendelkeznek, valamint a rák megelőzésében is szerepet játszanak, és egyben a fehérjék, ásványi elemek biohasznosulását is csökkenthetik. A quinoa felhasználása széleskörü, leginkább köretként ismeretes, de fogyasztják italként, kenyérként, tésztaként és sütőipari termékek formájában egyaránt (SCHOENLECHNER, 2017).

\section{ANYAg ÉS MÓDSZER - MATERIAL AND METHODS}

\subsection{Alapanyagok - Raw Materials}

A próbatermékek előállításához a legfontosabb alapanyag számunkra az álgabonák lisztje volt, így hajdina, amaránt és quinoa lisztek beszerzése volt az első feladat. További gluténmentes lisztek, mint a rizsliszt és a gesztenyeliszt, egyéb hozzávalók (tej, vaj, tojás, száraz élesztő, cukor, só) és dúsítóanyagokként olajos magvak (napraforgómag, tökmag) is szükségesek voltak. Minden szükséges anyagot közforgalomból szereztünk be.

\subsection{A próbatermékek előállításának alapja - Basis of Preparing Pilot Products}

A termékek előállításának alapját a MAGYAR ÉLELMISZERKÖNYV 2-103 számú irányelve adta. A „Különleges minőségű dúsított sütemény termékcsoportjának” megfelelő termék előállítása volt a cél, a búzaliszt álgabonával és lisztkeverékkel való kiváltásának módosításával. A lisztek típusát és arányát MERT et al. (2015) és BRITES et al. (2018) kutatásuk alapján alkalmaztuk: 80:20 arányban hajdina/ amaránt/quinoa és rizs/gesztenye, valamint 60:40 arányban hajdina/amaránt/quinoa és rizs/gesztenye. Mindemellett szükségesnek tartottuk a kontroll minták elkészítését, mely szerint $100 \%$-ban alkalmaztuk a hajdina, az amaránt vagy a quinoa liszteket. Összesen 15 féle terméket készítettünk. A lehetséges hozzávalókat és dúsítóanyagokat a Magyar Élelmiszerkönyv előírása alapján alkalmaztuk, ahol a tej vagy annak helyettesítésére a tejpor és vaj meghatározott előírása van szigorúan megszabva. A további hozzávalók és dúsítóanyagok arányát saját fejlesztés alapján határoztuk meg, melyek szerint a következő arányokat alkalmaztuk: tej - 30\%, tojás - 25\%, vaj - 10\%, magvak $-5 \%$, cukor $-2,5 \%$, száraz élesztő $1,5 \%$, só - $1 \%$. 


\subsection{A vizsgálati módszerek - Methods of Measurements}

A termékprototípusok elkészítését a Debreceni Egyetem Mezőgazdaság-, Élelmiszertudományi és Környezetgazdálkodási Kar Élelmiszertechnológiai Intézetének Élelmiszeripari Innovációs Központjában végeztük el 2018-ban. Az alapanyagok kimérése és keverése után, azokat 10 percen keresztül $4{ }^{\circ} \mathrm{C}$-on pihentettük.
A sütéshez azonos tömegű mintákat mértünk ki. A sütési paraméterek azonosak volt minden próbatermék esetén, a sütési hőfok $180{ }^{\circ} \mathrm{C}$ volt és 20 percig tartott. A sütési veszteséget adott képlet alapján határoztuk meg, $\left(\mathrm{m}_{\mathrm{o}}-\mathrm{m}_{1} /\right.$ mo)*100. A minták térfogatának meghatározását repcemagos kiszorításos módszerrel végeztük el (AACC INTERNATIONAL, 2000) (1. kép).

1. KÉP

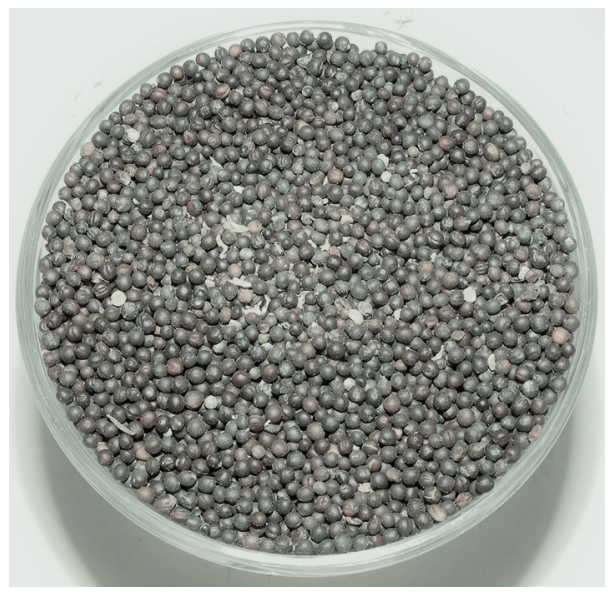

Repcemagos térfogatmérés

PIC. 1

(Measurement of Volume by Rapeseed)

Forrás (Source): Saját szerkesztés (Own compilation)

Ezt követően meghatároztuk a minták fehérjetartalmát (MSZ EN 12135:1999) és zsírtartalmát (MSZ 6369-15:1982) a vonatkozó Magyar Szabványok szerint. Az alapanyagokból számításos módszer alapján megadtuk a minták energiatartalmát. Az érzékszervi bírálatot kérdőíves felméréssel végeztük. A válaszadók íz, illat, állag és küllem alapján értékelhették a próbatermékeket 1-től 5-ig terjedő skálán, valamint külön leírhatták véleményüket, javaslatukat a próbatermékek minőségével kapcsolatban (Függelék). A próbatermékek színére vonatkozóan külön kérdés nem szolgált, azt a küllem értékelésénél adhatták meg a válaszadók, valamint a megjegyzésben tüntethették fel észrevételeiket erre vonatkozóan. Összesen 42 fó vett részt a felmérésben. A nemek aránya szerinti megoszlás alapján 27 nő (64\%) és 15 férfi (36\%) értékelte a próbatermékeket. A korcsoportok szerint 23 fó (52\%) tartozott a 18-25 év közöttiekhez, 13 fő (31\%) a 26-35 év közöttiekhez, valamint 7 fö (17\%) a 36 és idősebb korosztályt képviselőihez. A válaszadók többsége élelmiszermérnök képzésben részt vevő hallgatók voltak. A megkérdezettek közül 2 fő jelezte, hogy gluténérzékeny, valamint további 1 fó jelezte, hogy lehetőség szerint kerüli a glutént tartalmazó ételeket.

\section{EREDMÉNYEK - RESUltS}

Az elkészült próbatermékeket a 2. kép szemlélteti, ahol az álgabonák és a további lisztek különböző arányokban való felhasználásának eredményei láthatóak. 


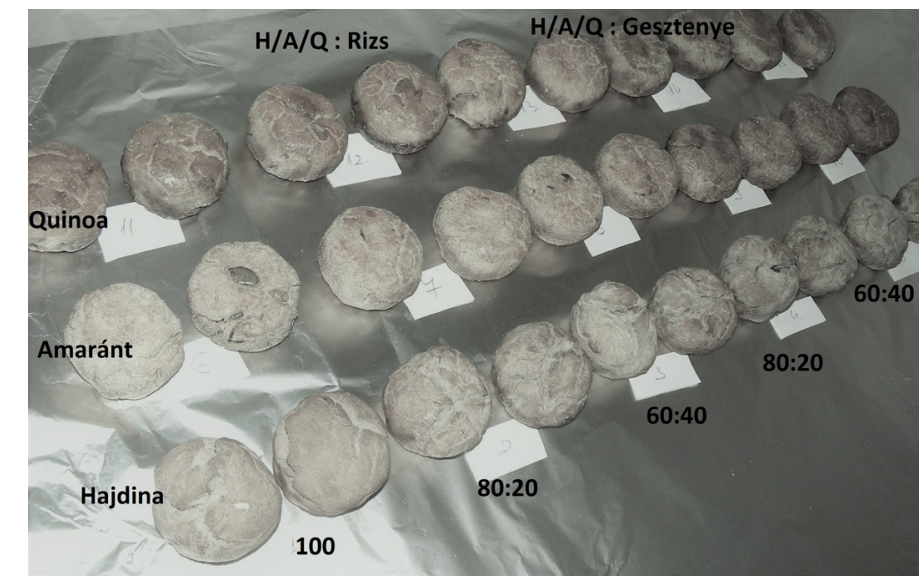

2. KÉP

Az elkészült próbatermékek

PIC. 2

Forrás (Source): Saját szerkesztés (Own compilation)

3.1. A próbatermékek sütési veszteségének és térfogatainak eredményei The Results of Baking Loss and Value of Pilot Products

Az 1. ábrán a próbatermékek sütési veszteség eredményei láthatóak. A hajdinával készült próbatermékek esetében a legnagyobb veszteséget a hajdina-rizsliszt 60:40 arányban való alkalmazásánál figyelhettük meg, 12,5\%. A gesztenyeliszttel készített próbatermék eredményezte a legkisebb veszteséget, így 20\%-os alkalmazásánál 8,7\%, míg 40\%-os alkalma- zásánál már csupán 5,8\%-os veszteséget figyelhettünk meg. Az amaránt liszttel készített próbatermékek mutatták a legnagyobb sütési veszteséget a hajdinás és a quinoás próbatermékekkel szemben, mely értékek 13,3-14,2\% között mozogtak. A quinoa liszttel készült sütemények esetén azt tapasztaltuk, hogy - a hajdinás próbatermékekkel ellentétben - a gesztenye liszt emelte a sütési veszteséget (12,5-14,2\%), a kontroll (10,0\%) és a rizslisztes próbatermékek (10,9\%) esetében emelkedett a legkevésbé ez az érték.

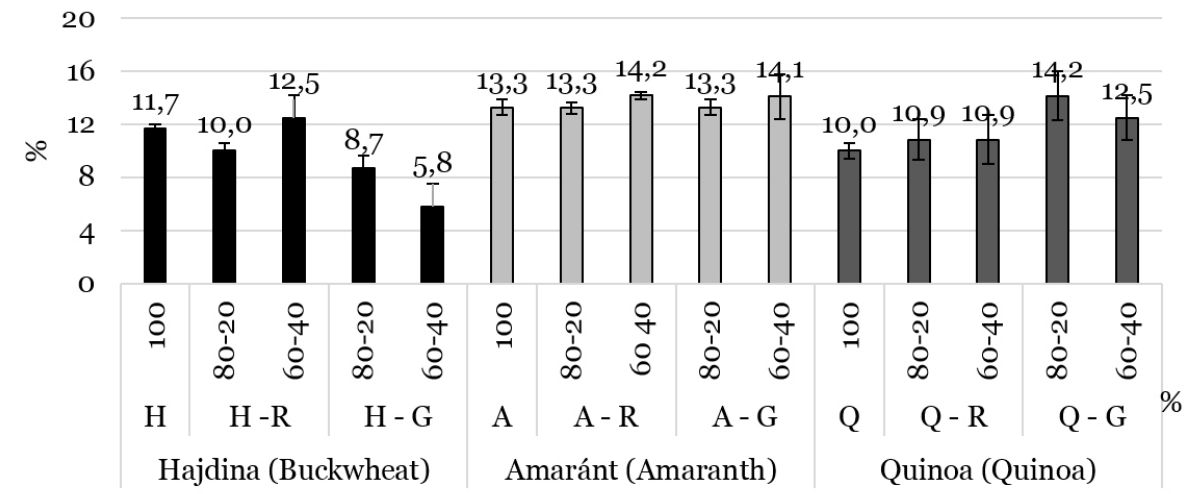

1. ÁBRA

A próbatermékek sütési veszteségének eredményei (The Results of Baking Loss of Pilot Products)

Forrás (Source): Saját szerkesztés (Own compilation)

Megjegyzés (Notes): H - hajdinaliszt (buckwheat flour), A - amarántliszt (amaranth flour), Q - quinoaliszt, R - rizsliszt (rice flour), $\mathrm{G}$ - gesztenyeliszt (chestnut flour) 
A minták térfogatát vizsgálva azt tapasztaltuk (1. táblázat), hogy a hajdina és a quinoa kontroll próbatermékek, azaz 100\%-ban való alkalmazásuk eredményezte a legnagyobb térfogat-értékeket, 72 és $75 \mathrm{~cm}^{3}$. A hajdinás próbatermékeknél a rizsliszt és a gesztenyeliszt csökkentették a próbatermékek térfogatát (64$\left.67 \mathrm{~cm}^{3}\right)$. A quinoa liszttel készített próbatermékek esetében a rizsliszt enyhén $\left(74 \mathrm{~cm}^{3}\right)$, míg a gesztenye már nagymértékben csökkentette a minták térfogatát (64-66 $\left.\mathrm{cm}^{3}\right)$. Ezzel szem- ben az amaránt liszttel készült próbatermékek esetében ennek ellenkezőjét figyelhettük meg, ugyanis a kontroll próbatermék mutatta a legalacsonyabb eredményt, míg a rizsliszt és a gesztenye liszt is növelték az értékeket. A kontroll esetében $65 \mathrm{~cm}^{3}$-t mértünk, a rizsliszt 20\%-os és 40\%-os alkalmazásánál $66 \mathrm{~cm}^{3}$-t vizsgáltunk, míg a gesztenyeliszttel készített próbatermékek esetén, mindkét arányban való alkalmazásánál is már 68 cm³ volt ez érték.

1. TÁBLÁZAT A próbatermékek térfogat-értékeinek eredményei
(The Results of Volume of Pilot Products)

TABLE 1

\begin{tabular}{|c|c|c|c|}
\hline $\begin{array}{c}\text { Álgabonák } \\
\text { (Pseudocereals) }\end{array}$ & $\begin{array}{l}\text { Lisztek } \\
\text { (Flours) }\end{array}$ & $\begin{array}{l}\text { Arányok } \\
\text { (Ratio), \% }\end{array}$ & $\begin{array}{c}\text { Érték (Value), } \\
\mathrm{cm}^{3}\end{array}$ \\
\hline \multirow{5}{*}{$\begin{array}{l}\text { Hajdina } \\
\text { (Buckwheat) }\end{array}$} & Hajdina (Buckwheat) & 100 & $72 \pm 3$ \\
\hline & Hajdina - Rizs (Buckwheat - Rice) & $80: 20$ & $70 \pm 1$ \\
\hline & Hajdina - Rizs (Buckwheat - Rice) & $60: 40$ & $67 \pm 1$ \\
\hline & Hajdina - Gesztenye (Buckwheat - Chestnut) & $80: 20$ & $66 \pm 2$ \\
\hline & Hajdina - Gesztenye (Buckwheat - Chestnut) & $60: 40$ & $64 \pm 3$ \\
\hline \multirow{6}{*}{$\begin{array}{l}\text { Amaránt } \\
\text { (Amaranth) }\end{array}$} & Amaránt (Amaranth) & 100 & $65 \pm 2$ \\
\hline & Amaránt - Rizs (Amaranth - Rice) & $80: 20$ & $66 \pm 3$ \\
\hline & Amaránt - Rizs (Amaranth - Rice) & $60: 40$ & $66 \pm 3$ \\
\hline & Amaránt - Gesztenye (Amaranth - Chestnut) & $80: 20$ & $68 \pm 2$ \\
\hline & Amaránt - Gesztenye (Amaranth - Chestnut) & $60: 40$ & $68 \pm 3$ \\
\hline & Quinoa (Quinoa) & 100 & $75 \pm 1$ \\
\hline \multirow{4}{*}{$\begin{array}{l}\text { Quinoa } \\
\text { (Quinoa) }\end{array}$} & Quinoa - Rizs (Quinoa - Rice) & $80: 20$ & $74 \pm 2$ \\
\hline & Quinoa - Rizs (Quinoa - Rice) & $60: 40$ & $74 \pm 1$ \\
\hline & Quinoa - Gesztenye (Quinoa - Chestnut) & $80: 20$ & $66 \pm 1$ \\
\hline & Quinoa - Gesztenye (Quinoa - Chestnut) & $60: 40$ & $64 \pm 2$ \\
\hline
\end{tabular}

Forrás (Source): Saját szerkesztés (Own compilation)

\subsection{A próbatermékek tápértékeinek eredményei - Nutritional Value of Pilot Products}

A minták tápértékére vonatkozó adatokat a 2. táblázatban szemléltetjük. A fehérjetartalom tekintetében a kontroll minták mutatták a legmagasabb értékeket. A hajdinával készült sütemény esetén ez az érték 10,69\%. A legalacsonyabb fehérjetartalom a 40\%-ban gesztenyeliszttel készített próbatermék esetén volt megfigyelhető. Minden próbaterméket figyelembe véve az amaránt liszttel készült kontroll próbatermék esetén volt mérhető a legmagasabb fehérjetartalom, 12,36\%. A rizs- és gesztenyeliszt hozzáadásával csökkentek ezek az értékek, 10,01\% és 11,39\% között változtak. A 100\%-ban quinoaliszttel készült próbatermék esetén 11,32\%-os fehérjetartalmat mértünk. A rizsliszt hozzáadásával a próbatermékek fehérje-értéke 10,80-10,56\% közé csökkent, míg a gesztenyeliszt alkalmazásánál 9,38\% és 10,35\% közötti értékeket figyelhettünk meg.

A próbatermékek zsírtartalmát értékelve már nem tapasztaltunk hasonló tendenciát. Ezek az értékek magasnak tekinthetőek, me- 
lyek közel azonosak voltak a próbatermékek fehérjetartalmának értékeivel. A legmagasabb értéket minden minta esetében a 40\%-ban alkalmazott gesztenyeliszt hozzáadása eredményezte, a hajdina-gesztenye kombinációt alkalmazva 11,44\%, az amaránt-gesztenye keveréke $12,75 \%$, míg a quinoa-gesztenye ötvözete $12,35 \%$-ot jelentett.
A próbatermékek energiatartalma 1070,79 kJ és 1351,39 kJ között változott. Két esetben, a hajdina-gesztenye és az amaránt-gesztenye 60:40 arányban való alkalmazásánál figyelhettük meg a legmagasabb értékeket adott termékcsoport esetén. Ezzel szemben a quinoával készített süteményeknél a kontroll esetében mértük a legmagasabb energiatartalmat.

\section{TÁBLÁZAT}

TABLE 2

A próbatermékek tápértékére vonatkozó adatok (Nutritional Value of Pilot Products)

\begin{tabular}{|c|c|c|c|c|c|}
\hline $\begin{array}{c}\text { Álgabonák } \\
\text { (Pseudocereals) }\end{array}$ & $\begin{array}{c}\text { Lisztek } \\
\text { (Flours) }\end{array}$ & $\begin{array}{c}\text { Arányok } \\
\text { (Ratio), \% }\end{array}$ & $\begin{array}{c}\text { Fehérje } \\
\text { (Protein), \% }\end{array}$ & $\begin{array}{c}\text { Zsír } \\
\text { (Fat), \% }\end{array}$ & $\begin{array}{c}\text { Energia }^{1} \\
\text { (Energy), kJ }\end{array}$ \\
\hline \multirow{5}{*}{$\begin{array}{l}\text { Hajdina } \\
\text { (Buckwheat) }\end{array}$} & $\mathrm{H}$ & 100 & 10,69 & 10,33 & 1294,92 \\
\hline & $\mathrm{H}-\mathrm{R}$ & $80: 20$ & 10,04 & 8,34 & 1287,18 \\
\hline & $\mathrm{H}-\mathrm{R}$ & $60: 40$ & 9,42 & $9,5^{8}$ & 1279,45 \\
\hline & $\mathrm{H}-\mathrm{G}$ & $80: 20$ & 9,85 & 9,27 & 1301,00 \\
\hline & $\mathrm{H}-\mathrm{G}$ & $60: 40$ & 9,01 & 11,44 & 1307,08 \\
\hline \multirow{5}{*}{$\begin{array}{l}\text { Amaránt } \\
\text { (Amaranth) }\end{array}$} & A & 100 & 12,36 & 12,51 & 1070,79 \\
\hline & $A-R$ & $80: 20$ & 11,39 & 11,70 & 1107,88 \\
\hline & $A-R$ & $60: 40$ & 10,42 & 10,88 & 1144,97 \\
\hline & $A-G$ & $80: 20$ & 11,18 & 12,63 & 1121,70 \\
\hline & $\mathrm{A}-\mathrm{G}$ & $60: 40$ & 10,01 & 12,75 & 1172,61 \\
\hline \multirow{5}{*}{$\begin{array}{l}\text { Quinoa } \\
\text { (Quinoa) }\end{array}$} & $\mathrm{Q}$ & 100 & 11,32 & 11,90 & 1351,39 \\
\hline & $\mathrm{Q}-\mathrm{R}$ & $80: 20$ & 10,56 & 11,16 & 13332,36 \\
\hline & $\mathrm{Q}-\mathrm{R}$ & $60: 40$ & 9,80 & 10,48 & 1313,33 \\
\hline & $\mathrm{Q}-\mathrm{G}$ & 80:20 & 10,35 & 12,10 & 1346,18 \\
\hline & $\mathrm{Q}-\mathrm{G}$ & $60: 40$ & 9,38 & 12,35 & 1340,97 \\
\hline
\end{tabular}

Forrás (Source): Saját szerkesztés (Own compilation)

Megjegyzés (Notes): H - hajdinaliszt (buckwheat flour), A - amarántliszt (amaranth flour), Q - quinoaliszt, R - rizsliszt (rice flour), G - gesztenyeliszt (chestnut flour)

\subsection{Az érzékszervi bírálat eredményei - Results of Organoleptic Evaluation}

A próbatermékek organoleptikus bírálatát (2. ábra) elemezve azt figyelhettük meg, hogy a legkedvezóbb próbaterméknek a quinoa liszttel készült sütemény bizonyult. Ez leginkább illatának és puha állagának volt köszönhető. A hajdinával készített próbatermékek esetében leginkább azok külleme eredményezte a magasabb pontszámokat. Az amaránt liszttel készült sütemények legnagyobb előnye azok ropogós állagából adódott. A hajdinás és az amarántos próbatermékek esetében a rizsliszt hozzáadása minden szempontból javított a próbatermékek minőségén. Ezzel ellentétben a quinoa liszttel készült süteményeknél már a gesztenyeliszt jelenléte hozta meg a magasabb pontszámokat. A dúsítóanyagok tekintetében túlnyomó részt a napraforgómagot preferálták a válaszadók. Javaslatként szerepelt - többek között - a próbatermékek további olajos magvakkal való dúsítása is, de ezen álgabonák egymás kombinációival való előállításuk is. 


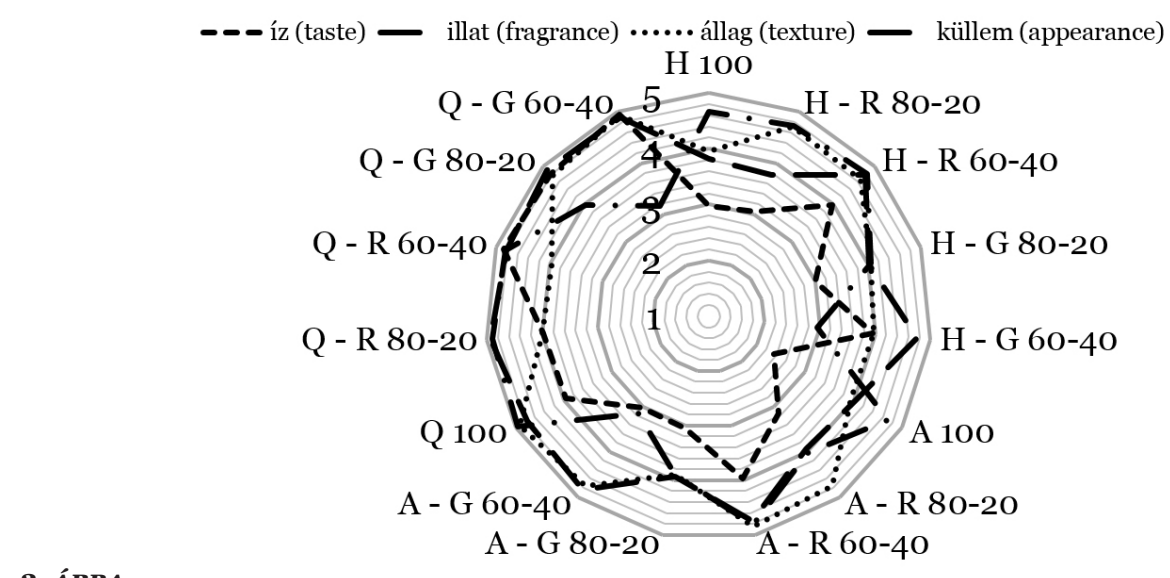

2. ÁBRA

FIG. 2

Forrás (Source): Saját szerkesztés (Own compilation)

Az organoleptikus bírálat eredménye

(Results of Organoleptic Evaluation)

Megjegyzés (Notes): H - hajdinaliszt (buckwheat flour), A - amarántliszt (amaranth flour), Q - quinoaliszt, R - rizsliszt (rice flour), G - gesztenyeliszt (chestnut flour)

\section{KöVETKEZTETÉSEK ÉS \\ JAVASLATOK - CONCLUSIONS AND PROPOSALS}

A pszeudocereáliák, mint ősi növényeink számos kedvező élettani hatással rendelkeznek. A receptúrák, melyek a MAGYAR ÉLELMISZERKÖNYV, a nemzetközi szakirodalmak (MERT et al., 2015; BRITES et al., 2018) és saját módosítás alapján készültek, jó alapot adtak ahhoz, hogy kedvező minőségü, dúsított próbatermékeket állítsunk elő. A gluténmentes lisztekkel változtatva a receptúrákat befolyásoltuk a késztermékek fizikai és kémiai paramétereit. Az organoleptikus bírálat értékelése során arra a következtetésre jutottunk, hogy az álgabonák többnyire jellegzetes érzékszervi tulajdonságait a legtöbb esetben kedvezően befolyásolták a különböző arányokban hozzáadott egyéb lisztek, illetve az olajos magvak. A fogyasztói megítélés alapján a kérdőívekben feltüntetett javaslatok további segítséget nyújtottak abban, hogy meghatározzuk a további fejlesztési irányvonalat annak érdekében, hogy még inkább kedvező tulajdonságokkal rendelkező és jobb minőségü próbatermékeket állítsunk elő.

\section{5. ÖSSZEFOGLALÁS - SUMMARY}

Kutatásunk célja volt, hogy olyan újszerű próbatermékek előállítását végezzük el, melyek kedvező táplálkozás-élettani hatással rendelkeznek. Elsősorban álgabonák felhasználási lehetőségeinek feltérképezése volt a feladatunk, így a hajdina, az amaránt és a quinoa lisztek voltak a legfontosabb alapanyagok számunkra. Ezen lisztek jellegzetes ízének javítása céljából további gluténmentes lisztek meghatározott arányokban való keverését és próbatermékek készítését végeztük el. Kísérletünk következő fontos célja volt a fogyasztói vélemények felmérése, ugyanis olyan visszajelzést kapunk, mely segítségével meg tudjuk határozni a további fejlesztésünk irányvonalát, hogy próbatermékünk kedvezóbb tulajdonságokkal rendelkezhessen. A fizikai vizsgálatok eredményei azt mutatták számunkra, hogy a kevésbé fogyasztott, nem hagyományos növények lisztjeiből is készíthetünk jó minőségű termékeket. A kémiai vizsgálatok alapján a próbatermékek kedvező fehérjetartalommal rendelkeztek, a zsír- és energiatartalmat további fejlesztések alkalmával csökkenteni kívánjuk. Az érzékszervi bírálat alapján volt, aki a quinoa liszttel készített próbaterméket részesítette előnyben, annak kedvező illata (átlagosan 5 pont) és puha álla- 
ga (átlagosan 4,6 pont) miatt, míg volt, aki inkább a ropogós állagot kedvelte (átlagosan 4,6 pont), így az amaránttal készült próbatermék nyerte el tetszését. Összességében elmondható, hogy az organoleptikus értékelés alapján a quinoa (kontroll), a quinoa-rizs (60:40), a quinoa-gesztenye (80:20), az amaránt-rizs
(60:40) és a hajdina-rizs (60:40) lisztek felhasználásával készült próbatermékek érték el a legmagasabb pontszámokat. Az adott elókísérletek és a fogyasztói megítélés alapját képezi a további termékfejlesztéseknek, valamint segítséget nyújt feladataink elvégzésében.

\section{FÜGGELÉK - ANNEX}

\section{Érzékszervi bírálat kérdôive (Questionnaire of organoleptic evaluation)}

1. Neme (Gender): $\square$ Nổ (Female) $\square \quad$ Férfi (Male)

2. Életkora (Age): $18-25$

$$
\begin{aligned}
& 26-35 \square \\
& 36 \leq \square
\end{aligned}
$$

3. Szenved-e ételallergiában? (Are You suffering from food allergies?) $\square \quad$ Igen (Yes) $\square$ Nem (No) Amennyiben igen, kérem, tüntesse fel az adott allergiát (If You suffering from food allergy, please describe it):

4. Értékelje az alábbi termékeket 1-5-ig terjedő skálán, ahol az 1 - a legkevésbé kedvezó, 5 - a leginkább kedvezô (Please evaluate the following products on a scale of 1 to 5, where 1 - the least favorable, 5 - the most favorable):

\begin{tabular}{|c|c|c|c|c|}
\hline $\begin{array}{c}\text { Termékek } \\
\text { (Products) }\end{array}$ & fz (Taste) & $\begin{array}{c}\text { Illat } \\
\text { (Fragrance) }\end{array}$ & $\begin{array}{c}\text { Allag } \\
\text { (Texture) }\end{array}$ & $\begin{array}{c}\text { Küllem } \\
\text { (Appearance) }\end{array}$ \\
\hline 1. & & & & \\
\hline 2. & & & & \\
\hline 3. & & & & \\
\hline 4. & & & & \\
\hline 5. & & & & \\
\hline 6. & & & & \\
\hline 7. & & & & \\
\hline 8. & & & & \\
\hline 9. & & & & \\
\hline 10. & & & & \\
\hline 11. & & & & \\
\hline 12. & & & & \\
\hline 13. & & & & \\
\hline 14. & & & & \\
\hline 15. & & & & \\
\hline
\end{tabular}

5. Preferált dúsítóanyag (Preferred enrichment agent):

- napraforgómag (sunflower seed)

- tökmag (pumpkin seed)

6. Kérem, jelezze egyéb észrevételeit, javaslatait az adott termékekkel kapcsolatban (Please indicate any other suggestions about the products): 


\section{KöSZÖNETNYILVÁNÍTÁs - ACKNOWLEDGEMENT}

Az Emberi Erőforrások Minisztériuma ÚNKP-18-3 kódszámú Új Nemzeti Kiválóság Programjának támogatásával készült.

\section{IRODALOMJEGYZÉK - REFERENCES}

AACC International: Method 10-05.01, Guidelines for Measurement of Volume by Rapeseed Displacement. Approved Methods of Analysis, 11th ed. AACC International, St. Paul, MN., 2000.

Brites, L. T. G. F. - Schmiele, M. - Steel, C. J.: Gluten-Free Bakery and Pasta Products. Alternative and Replacement Foods. 2018. 385-410. https://doi. org/10.1016/B978-0-12-811446-9.000137

D'Amico, S. - Schoenlechner, R.: Amaranth: Its Unique Nutritional and Health-Promoting Attributes. In: Gluten-Free Ancient Grains. Cereals, Pseudocereals, and Legumes: Sustainable, Nutritious, and Health-Promoting Foods for the 21st Century. (Ed.: Taylor, J. R. N. - Awika, J. M.) International Association for Cereal Science and Technology. Woodhead Publishing, 2017. 131-159. https://doi.org/10.1016/B978-0-o8100866-9.00006-6

Ferreira, T. A. D. C. - Areas, J. A. G.: Protein Biological Value of Extruded, Raw and Toasted Amaranth Grain. Pesquisa Agropecuaria Tropical. 2004. 34 53-59.

Fletcher, R. J.: Pseudocereals: Overview. Encyclopedia of Food Grains, Second Edition, 2016. 1 274-279. https://doi. org/10.1016/B978-0-12-394437-5.000395

Krkoškova, B. - Mrazova, Z.: Prophylactic Components of Buckwheat. Food Research International, 2005. 38 (5) 561-568. https://doi.org/10.1016/j. foodres.2004.11.009
Kumar, P. K. V. - Dharmaraj, U. Sakhare, S. D. - Inamdar, A. A.: Preparation of Protein And Mineral Rich Fraction from Grain Amaranth and Evaluation of its Functional Characteristics. Journal of Cereal Science. 2016. 69 (May) 358-362. https://doi. org/10.1016/j.jcs.2016.05.002

Léder, Fné. - Adányiné Kisbocskói, N. - Daood, H. - Kardos, Gyné. - Cserhalmi, Zs.: Pszeudo-cereáliák szerepe az egészséges táplálkozásban. Pohánka (hajdina) alapú élelmiszerek táplálkozási előnyei, a pohánka természetes antioxidáns hatású vegyületei. Élelmiszer Tudomány Technológia. 2012. 66 (3) 12-17.

Magyar Élelmiszerkönyv. Codex Alimentarius Hungaricus: 2-103 számú irányelv. Megkülönböztető minőségi jelöléssel ellátott sütőipari termékek. „Különleges minőségű dúsított sütemény termékcsoport”, 13.

Mert, S. - Sahin, S. - Sumnu, G.: Development of Gluten-Free Wafer Sheet Formulation. LWT - Food Science and Technology. 2015. 63 (2) 1121-1127. https://doi.org/10.1016/j.lwt.2015.04.035

MSZ EN 12135:1999.: Gyümölcs- és zöldséglevek. A nitrogéntartalom meghatározása. Kjeldahl-módszer, 1999.

MSZ 6369-15:1982.: Nyerszsír és avasság meghatározása, 1982. 
Schoenlechner, R.: Quinoa: Its Unique Nutritional and Health-Promoting Attributes. In: Gluten-Free Ancient Grains. Cereals, Pseudocereals, and Legumes: Sustainable, Nutritious, and Health-Promoting Foods for the 21st Century. (Ed.: Taylor, J. R. N. - Awika, J. M.) International Association for Cereal Science and Technology. Woodhead Publishing, 2017. 105-129. https:// doi.org/10.1016/B978-0-08-1008669.00005-4

Taylor, J. R. N.: Environmental, Nutritional, and Social Imperatives for Ancient Grains. In: Gluten-Free Ancient Grains. Cereals, Pseudocereals, and Legumes: Sustainable, Nutritious, and Health-Promoting Foods for the 21st Century. (Ed.: Taylor, J. R. N. - Awika, J. M.) International Association for Cereal Science and Technology. Woodhead Publishing, 2017.1-12. https:// doi.org/10.1016/B978-0-08-1008669.00001-7
Tömösközi, S. - Langó, B.: Buckwheat: Its Unique Nutritional and HealthPromoting Attributes. In: Gluten-Free Ancient Grains. Cereals, Pseudocereals, and Legumes: Sustainable, Nutritious, and Health-Promoting Foods for the 21st Century. (Ed.: Taylor, J. R. N. - Awika, J. M.) International Association for Cereal Science and Technology. Woodhead Publishing, 2017. 161-177. https:// doi.org/10.1016/B978-0-08-1008669.00007-8

Venskutonis, P. R. - Kraujalis, P.: Nutritional Components of Amaranth Seeds and Vegetables: A Review on Composition, Properties, and Uses. Comprehensive Reviews in Food Science and Food Safety, 2013. 12 381-412. https://doi.org/10.1111/1541-4337.12021

\section{JEGYZETEK * NOTES}


JEGYZETEK $\nRightarrow$ NOTES 